INDEPENDENT JOURNAL OF MANAGEMENT \& PRODUCTION (IJM\&P)

http://www.ijmp.jor.br

v. 8, n. 5, Special Edition IFLOG 2016

ISSN: 2236-269X

DOI: 10.14807/ijmp.v8i5.598

\title{
EVALUATION OF PMBOK AND SCRUM PRACTICES FOR SOFTWARE DEVELOPMENT IN THE VISION OF SPECIALISTS
}

\author{
Elton Fernandes Gonçalves \\ Universidade Federal Fluminense, Brazil. \\ E-mail: eltonfg82.rj@gmail.com \\ Geisa Meirelles Drumond \\ Universidade Federal Fluminense, Brazil. \\ E-mail: gmdrumond@vm.uff.br \\ Mirian Picinini Méxas \\ Universidade Federal Fluminense, Brazil. \\ E-mail:mirian_mexas@vm.uff.br
}

Submission: 03/01/2017

Accept: 12/01/2017

\section{ABSTRACT}

In project management, the challenge for software development is to achieve success for the proposed projects, using methods such as PMBOK and Scrum. Knowledge of the advantages of these methods are critical success factors for product development. Therefore, the proposal of this study was to verify the perception of specialists of the area of software development on practices of project management. The used methods in this study were the bibliographic, exploratory and qualitative research, with the construction of a questionnaire with 14 items on the advantages of project management practices of various natures, size and complexity, which were applied in 90 specialists. The results of the research demonstrated that all the experts agreed with the advantages of the project management practices, identified based on the literature review, for software development, thus validating the proposed items of the questionnaire. It is recommended for future researches the accomplishment of case studies that explore practical models of evaluation of the use of the practices studied in the scope of software development. It is important in the future studies that metrics and indicators be drawn for each of the advantages cited in the present study. 
INDEPENDENT JOURNAL OF MANAGEMENT \& PRODUCTION (IJM\&P)

http://www.ijmp.jor.br

v. 8, n. 5, Special Edition IFLOG 2016

ISSN: 2236-269X

DOI: 10.14807/ijmp.v8i5.598

Keywords: Project management, Software development, PMBOK, SCRUM

\section{INTRODUCTION}

The context in which organizations around the world operate is becoming increasingly complex and competitive. The speed at which cultural, political, economic, and social changes are taking place naturally presents opportunities and threats that impact the achievement of the organizational mission, whether of public administration organizations, business entities or non-profit entities (HORTA, 2009).

Organizations often experience partial or total failure with regard to the scope, quality, timing, and cost planned in their projects and programs. In spite of the existence of vast literature on the subject and intense work of international organizations such as the International Project Management Association (IPMA), the Project Management Institute (PMI) and the Association for Project Management (APM), which bring together professionals of different backgrounds and performance in several countries of the world (BARRETTO et al., 2008), it is still possible to verify a large percentage of project failure, which according to Shenhar and Dvir (2007), in the field of organizational strategies, these initiatives have failed suggesting that Projects Management such as discipline and methodology has been largely neglected.

Thomsett (2001) states that a project can address a number of quality considerations, and these vary according to how each stakeholder sees the project. The development team cares about the technical aspects while business analysts and project managers care about managerial aspects. Among the technical aspects can be mentioned the specification of functionalities, the data model, the test plan and the project documentation, etc. The managerial aspects are those dealing with aspects such as resource allocation, project priorities, risk analysis, return on investment and cost estimates, etc. In this way, the selected methodology must support the interests of both groups.

According to Cockburn (2000), every project needs its own methodology and each methodology has a specific weight. The weight, according to the author, is composed of two components: the size that corresponds to the number of elements in the methodology and the density that corresponds to the "rigour" with which these elements must be realized. 
INDEPENDENT JOURNAL OF MANAGEMENT \& PRODUCTION (IJM\&P)

http://www.ijmp.jor.br

v. 8, n. 5, Special Edition IFLOG 2016

ISSN: 2236-269X

DOI: 10.14807/ijmp.v8i5.598

Practices involving identification and prior treatment regarding risks and uncertainties that may affect project performance are of fundamental importance in the business environment, where pressure for results is one of the major factors involved because of the competitive nature of this scenario. (DEY; CLEGG; BENNETT, 2010).

One challenge is to make every software development project achieve success for it. In this sense, the search for a proper methodology for each project becomes a fundamental issue for their success (COCKBURN, 2000).

Within this context, the correct choice of methodology in software development becomes a critical factor for success in this segment.

Thus, the proposal of this study was to verify the perception of specialists on project management practices, identified based on the literature review, for the area of software development.

\section{LITERATURE REVIEW}

This section presents concepts about the software development process and its relationship with project management.

\subsection{Software Development Process}

According to Sommerville (2004), a software development process can be defined as a set of activities, methods, practices and transformations that people employ to develop and maintain software and associated products (for example, project plans, project documents, design, code, test cases, user manual).

For Pressman (2006), the software process is the set of partially ordered activities that a project must follow to perform some task. This task should aim to achieve a certain goal and is usually, associated with the development of one or more products.

Some models of software development can be cited:

- $\quad$ Classic model or Waterfall, one of the most widespread and used, was the first model of software development. This model uses a systematic and sequential approach in software development and uses the following steps: (1) Requirements analysis, (2) Analysis, (3) Design, (4) Coding, (5) Testing and (6) Maintenance (PRESSMAN, 2006). 
- $\quad$ Prototyping model allows the developer to create a model of the software that will be developed. It is based on the following steps (1) Listen to the client, (2) Build / revise the prototype and (3) Test / evaluate the prototype (PRESSMAN, 2006).

- Incremental model assumes that a given software does not have to be completed in its entirety in order to be delivered to users, this model seeks to divide the development process into parts, called incremental, functional, thus anticipating the user's contact with the product being developed. This model was developed from the classic model, including the interactive prototyping philosophy (PRESSMAN, 2006).

- $\quad$ Spiral model was developed in order to contain the best characteristics of the classic models and prototyping, with the addition of the risk analysis. The spiral model uses four quadrants (1) Planning, (2) Risk analysis, (3) Engineering and product development, and (4) Customer assessment. At the end of each iteration around the spiral (starting from the center and advancing outward), progressively more complete versions of the software are generated (PFLEEGER, 2004).

- Fourth-generation techniques, this paradigm focuses on the ability to specify software close to the natural language. This model uses the following steps (1) Requirements collection, (2) Project strategy, (3) Implementation using 4th Generation Techniques and (4) Test (PRESSMAN, 2006).

Software development processes act as guides for the execution of all projects within an organization.

\subsection{Project Management}

To better understand project management it is fundamental to understand the concept of design. Schwalbe (2002) defines a project as a temporary enterprise with the objective of producing a single product or service.

The definition given by Dinsmore and Silveira Neto (2005, p.1)

A project is a temporary effort made to create a unique product or service, unlike any other, of all other products and services, with beginning and end, defined, which uses resources, is managed by people and obeys the parameters of cost, time and quality. 
INDEPENDENT JOURNAL OF MANAGEMENT \& PRODUCTION (IJM\&P)

http://www.ijmp.jor.br

v. 8, n. 5, Special Edition IFLOG 2016

ISSN: 2236-269X

DOI: 10.14807/ijmp.v8i5.598

In this way, a project can be defined as a non-repeatable enterprise, with a clear and logical sequence, with defined beginning and end and with the specific and defined objective. In turn, being conducted by people respecting the predefined parameters of cost, time, resources involved and quality, as stated by Martins (2002).

Project Management practices are presented as methods or guides, known as Traditional Methods and Agile Methods (SHENNAR; DVIR, 2007), which are a set of actions, techniques and tools to manage projects.

Among the traditional methods, we highlight the Project Management Body of Knowledge (PMBOK), which divides a project into a set of phases, which it calls the project life cycle. Life cycles, in turn, have phases that link the beginning and end of a project. The transitions that occur between phases usually involve some type of delivery, or a technical transfer. Usually the project life cycles define what work will be done in each phase, as well as the involved ones and the procedures regarding the control and approval of each phase (PROJECT MANAGEMENT INSTITUTE, 2013).

In addition, the PMBOK has five groups of project management processes that are interdependent. Thus, in process groups, the outputs of a process become inputs to another process or are deliveries of the project. The PMI also describes that these activities are overlapping and occur at varying levels of intensity throughout the project. Thus, for projects that are divided into phases, the process groups interact within a project phase and may cross several phases of the project, as shown in Figure 1.

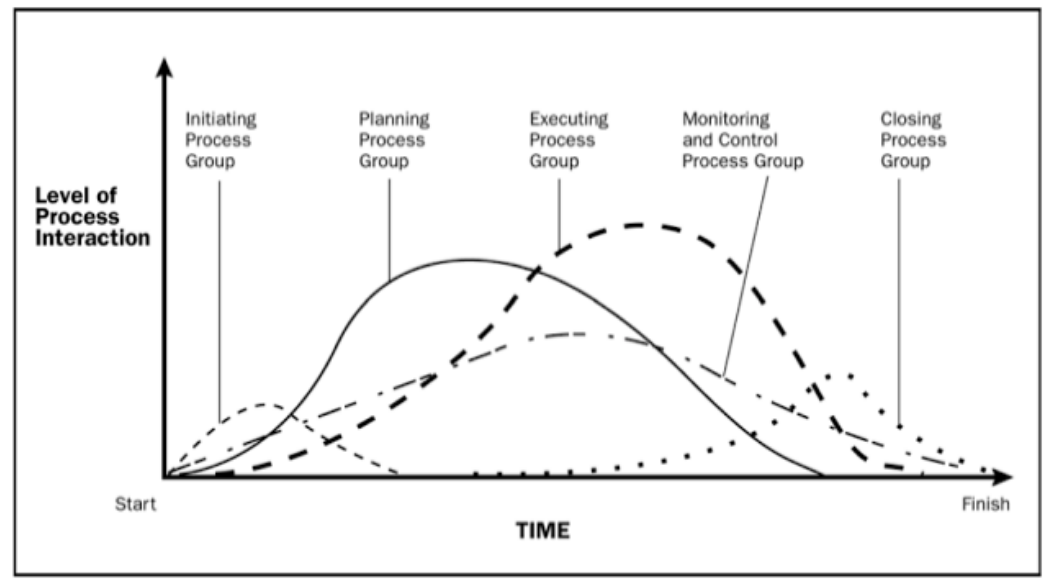

Figure 1: Process groups interact in a phase or a project. Source: PMI (2013). 
INDEPENDENT JOURNAL OF MANAGEMENT \& PRODUCTION (IJM\&P)

http://www.ijmp.jor.br

v. 8, n. 5, Special Edition IFLOG 2016

ISSN: 2236-269X

DOI: 10.14807/ijmp.v8i5.598

For scenarios characterized by constant changes of requirements and the need to perform deliveries in a short time, it is recommended to use agile methods for product development.

In general, agile methods divide development into several short iteration cycles, and at the end of each cycle deliveries are made, so that "[...] the customer (internal or external) receives a version that adds value to their business" (DANTAS, 2003, p.37). In this way, developers can track requirements changes at the beginning of each cycle. This provides customer feedback to the development team, which reduces project risk.

The principles of lean manufacturing, implemented by Honda and Toyota companies, and Takeuchi and Nonaka (2004) and Senge (1990) knowledge management strategies strongly influenced these methods.

Among the agile methods of product development, we highlight the Scrum method, which aims to define a project development process focused on the people of the team (SCHWABER; BEEDLE, 2002).

The Scrum method is indicated to manage the software development process in environments where the requirements undergo constant changes (ABRAHAMSSON et al., 2002).

The Figure 2 illustrates the evolution of the cascade process model for Scrum, showing adaptability used in agile methods in contrast with the inherent predictability to prescriptive or traditional models.

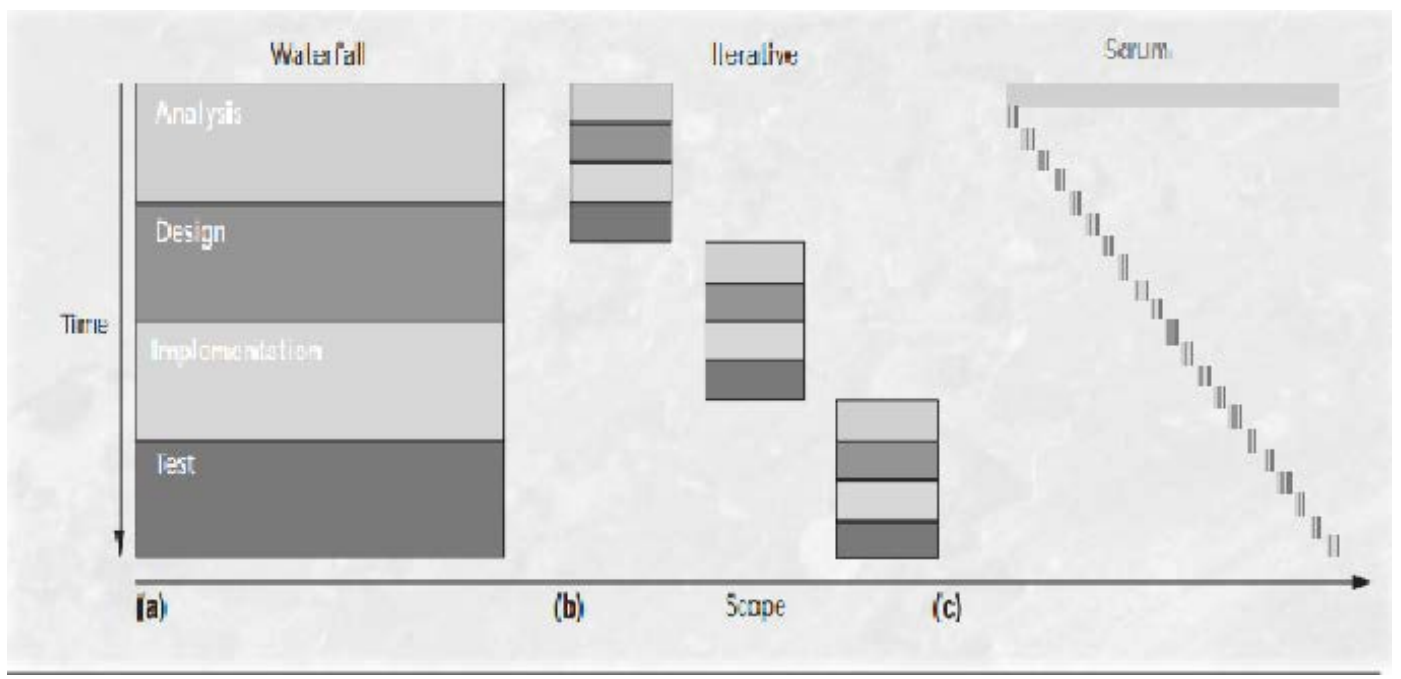

Figure 2: Evolution of the Cascading Model for Scrum.

Source: Beck (1999). 
The legend (a) presents the waterfall model having its activities distinguished in grayscale, showing that it is a cycle with long duration. In (b), the cycles are shorter. The evolution of iterative development to agile methods is observed in Scrum in (c), where analysis, design, coding and testing activities are combined in short periods throughout the project.

\section{METHODOLOGY}

In this study, the bibliographic research in the SciELO and Scopus bases was used to identify a set of advantages related to the management practices of projects of various natures, size and complexity, characterizing, in this sense, as an exploratory research.

Based on the literature review in the aforementioned databases, the data collection instrument was proposed: a questionnaire to evaluate the perception of project management professionals regarding the advantages of the PMBOK and Scrum practices. The authors in which the advantages of the PMBOK and Scrum practices were identified were: Carvalho and Mello (2012), Cervone (2011), Eder et al. (2012, 2015), Ghosh et al. (2012), Kaiser et al. (2015), King (2014), Lacerda et al. (2011), Landaeta et al. (2011), Machado et al. (2015) and Nascimento et al. (2014).

Table 1 shows the 13 criteria that were used in the questionnaire of this research, in order to obtain the users' perceptions of the process regarding their degree of agreement. The criteria were consolidated using similarity of the nomenclature used by different authors.

Table 1: Evaluated criteria in the questionnaire applied

\begin{tabular}{|c|c|}
\hline Criteria & Criteria Description \\
\hline $\begin{array}{l}\text { Detail of Planning and Control proposed by } \\
\text { the PMBOK }\end{array}$ & $\begin{array}{l}\text { Further documentation on the planning and } \\
\text { control aspects of the project progress. }\end{array}$ \\
\hline $\begin{array}{l}\text { Improved communication among team } \\
\text { members. (Scrum and PMBOK) }\end{array}$ & $\begin{array}{l}\text { Improvement of communication where all } \\
\text { team members use a common language for } \\
\text { communication. }\end{array}$ \\
\hline $\begin{array}{l}\text { Short-term learning through Iteration } \\
\text { Retrospective (Scrum) }\end{array}$ & Learning faster, after completing the iteration. \\
\hline Ease of use of Scrum & $\begin{array}{l}\text { Ease of use of Scrum practices due to its } \\
\text { flexibility of application. }\end{array}$ \\
\hline More detailed documentation by PMBOK. & $\begin{array}{l}\text { Detailed control of various processes relevant } \\
\text { to the project. }\end{array}$ \\
\hline Product running $\mathrm{i}$ & $\begin{array}{l}\text { Delivery of product ready and working at the } \\
\text { end of each iteration. }\end{array}$ \\
\hline $\begin{array}{l}\text { Increased team motivation resulting from the } \\
\text { use of Scrum practices }\end{array}$ & $\begin{array}{l}\text { Increased motivation of team members } \\
\text { resulting from Scrum practices. }\end{array}$ \\
\hline $\begin{array}{l}\text { Increased control of project activities resulting } \\
\text { from Daily Meetings resulting from the use of }\end{array}$ & $\begin{array}{l}\text { Greater control of activities, daily resulting } \\
\text { from Daily Meetings. }\end{array}$ \\
\hline
\end{tabular}


ISSN: 2236-269X

DOI: 10.14807/ijmp.v8i5.598

\begin{tabular}{ll}
\hline Scrum practices. & \\
\hline $\begin{array}{l}\text { Improved collaboration among stakeholders } \\
\text { from the use of Scrum practices. }\end{array}$ & $\begin{array}{l}\text { Greater involvement and collaboration among } \\
\text { team members. }\end{array}$ \\
\hline $\begin{array}{l}\text { Visibility of activities by all team members } \\
\text { resulting from the use of Scrum practices. }\end{array}$ & $\begin{array}{l}\text { Visibility of project activities by all team } \\
\text { members. }\end{array}$ \\
\hline $\begin{array}{l}\text { High agility for requirement adjustment at } \\
\text { design time. }\end{array}$ & $\begin{array}{l}\text { Ease of adjustment of requirements at design } \\
\text { time due to short deliveries of product } \\
\text { running. Feedback speed }\end{array}$ \\
\hline $\begin{array}{l}\text { Scrum practices can contribute to project } \\
\text { closure faster. }\end{array}$ & $\begin{array}{l}\text { Closure of the project more quickly, mainly } \\
\text { due to feedback generated by the short } \\
\text { deliveries. Thus avoiding rework. }\end{array}$ \\
\hline $\begin{array}{l}\text { Scrum practices can contribute to lower } \\
\text { project costs. }\end{array}$ & $\begin{array}{l}\text { Decrease in project costs mainly due to the } \\
\text { rapid feedback generated by short deliveries. }\end{array}$ \\
\hline
\end{tabular}

A Likert scale was used to collect data on the degree of agreement of the research participants regarding the proposed criteria, according to Table 2. This scale was adopted based on Likert (1932) and Costa (2010).

\begin{tabular}{|c|c|c|c|c|}
\hline $\begin{array}{l}\text { Totally } \\
\text { Agree }\end{array}$ & $\begin{array}{l}\text { Partly } \\
\text { Agree }\end{array}$ & $\begin{array}{c}\text { Don't agree } \\
\text { nor disagree }\end{array}$ & $\begin{array}{c}\text { Partly } \\
\text { Disagree }\end{array}$ & $\begin{array}{c}\text { Totally } \\
\text { Disagree }\end{array}$ \\
\hline 5 & 4 & 3 & 2 & 1 \\
\hline
\end{tabular}

The questionnaire was applied to 90 specialists related to the development of new software products and that are located in companies of Rio de Janeiro and São Paulo, belonging to the private initiative or to the government.

The data obtained were treated using descriptive statistics techniques, whose objective, according to Larson and Farber (2007) is "to make it easier to understand the data and to see trends, averages and variations in them".

\section{ANALYSIS OF RESULTS}

This section deals with the analysis and results of this study and is organized in the following subsections: identification of respondents and analysis of the advantages of using project management practices using PMBOK and Scrum methods in the area of software development.

\subsection{Identification of Respondents}

The characterization of the respondents was obtained based on the following items:

1. Segment of the institution where you work

2. Practice Area

3. Experience time in the area 
INDEPENDENT JOURNAL OF MANAGEMENT \& PRODUCTION (IJM\&P)

http://www.ijmp.jor.br

v. 8, n. 5, Special Edition IFLOG 2016

ISSN: 2236-269X

DOI: 10.14807/ijmp.v8i5.598

The graphics 1, 2 and 3 show the answers of the respondents according to these items.

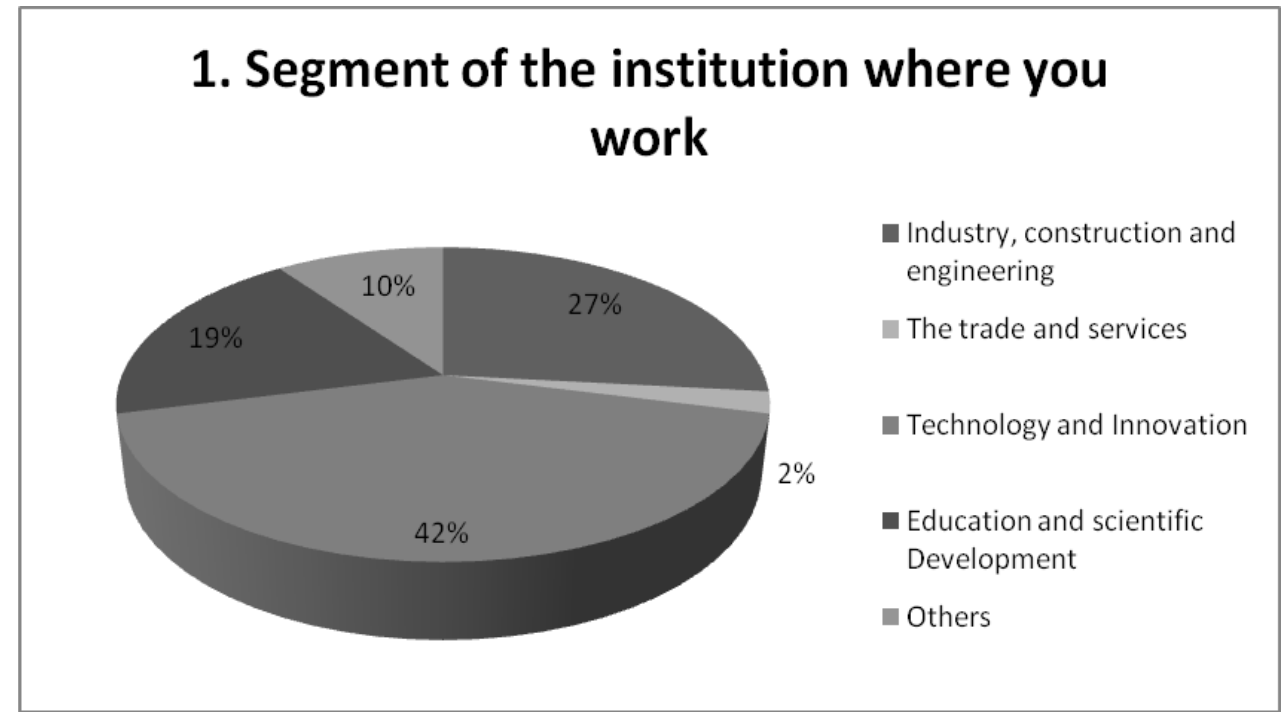

Graphic 1: Segment of the institution where you work

As for the first item, it was verified that the highest incidence of responses is concentrated in the area of Technology and Innovation with 42\%, the second most selected option with $27 \%$ was industry, construction and engineering, the third most selected option was Education and scientific Development with 19\%. The trade and services option obtained only $2 \%$, while the option "others" reached $10 \%$.

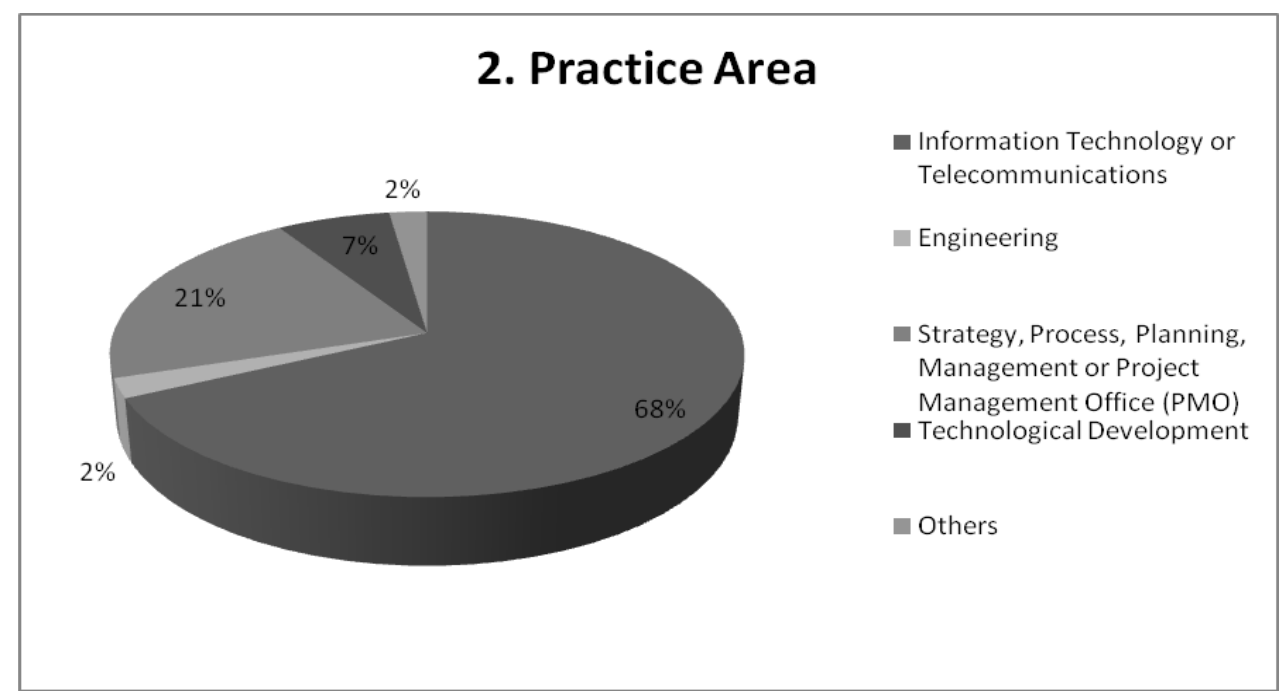

Graphic 2: Practice Area

As for the second item, the most answered that works on the Information Technology or Telecommunications sector, totaling 68\%. The second option with expressive volume of responses was Strategy, Process, Planning, Management or 
Project Management Office (PMO) with a total of $21 \%$. The other options and engineering obtained $2 \%$ each, while technological development obtained $7 \%$.

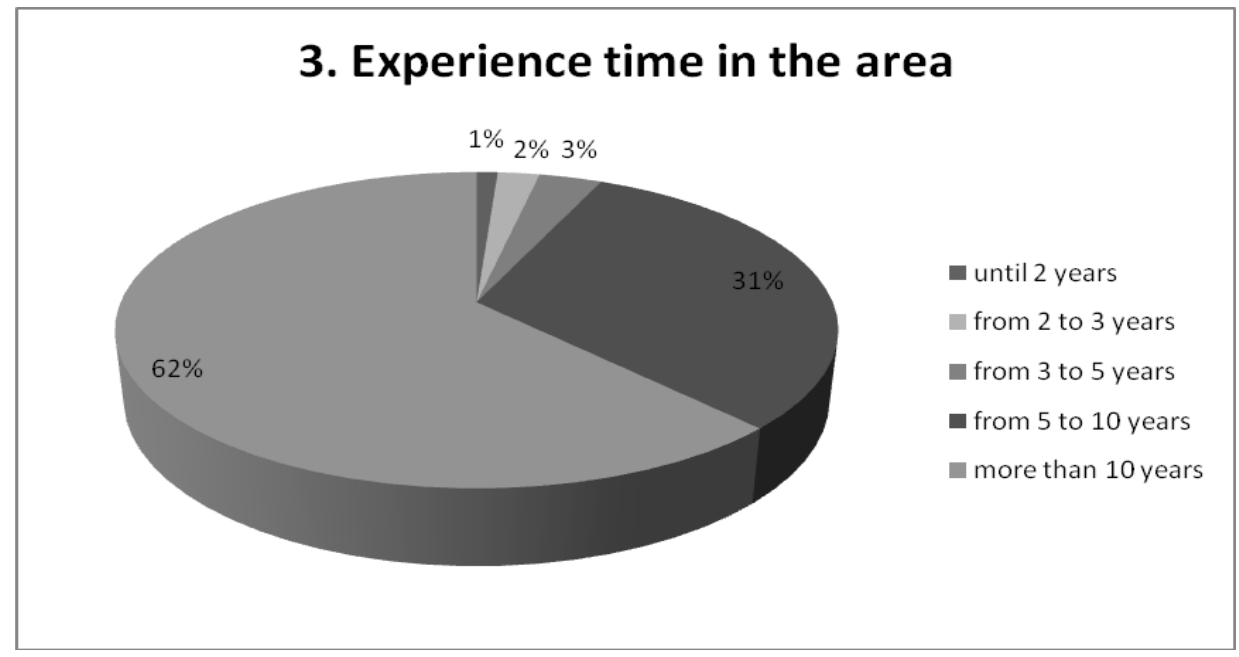

Graphic 3: Experience time in the area.

As for the third item, it can be verified that the absolute majority of the respondents has more than 10 years of experience, being a point that can be considered very positive, since it is a survey of opinion and perception. Altogether $62 \%$ of the respondents have more than 10 years of experience followed by $31 \%$ of respondents in the range of 5 to 10 years. The remaining $7 \%$ have less than 5 years' experience.

\subsection{Analysis of the advantages of using PMBOK and Scrum practices}

In the Table 3, the results obtained, as well as the evaluated items of the questionnaire applied to specialists in the area of software development, are presented.

Table 3. Summary of respondents' perceptions - Advantages

\begin{tabular}{l|l|c|c|c|c|c}
\hline & \multicolumn{1}{|c|}{ Rated Items } & \multicolumn{5}{c}{ Likert Scale } \\
\cline { 3 - 6 } & 5 & 4 & 3 & 2 & 1 \\
\hline $\mathbf{1}$ & $\begin{array}{l}\text { Detail of Planning and Control proposed } \\
\text { by the PMBOK }\end{array}$ & $26 \%$ & $54 \%$ & $7 \%$ & $12 \%$ & $1 \%$ \\
\hline $\mathbf{2}$ & $\begin{array}{l}\text { Improved communication among team } \\
\text { members. (Scrum and PMBOK) }\end{array}$ & $52 \%$ & $36 \%$ & $8 \%$ & $4 \%$ & $0 \%$ \\
\hline $\mathbf{3}$ & $\begin{array}{l}\text { Short-term learning through Iteration } \\
\text { retrospective (Scrum) }\end{array}$ & $52 \%$ & $37 \%$ & $8 \%$ & $3 \%$ & $0 \%$ \\
\hline $\mathbf{4}$ & Ease of use of Scrum & $40 \%$ & $43 \%$ & $12 \%$ & $5 \%$ & $0 \%$ \\
\hline $\mathbf{5}$ & Further documentation by PMBOK & $36 \%$ & $30 \%$ & $16 \%$ & $16 \%$ & $2 \%$ \\
\hline $\mathbf{6}$ & Product running in short periods in Scrum. & $46 \%$ & $36 \%$ & $13 \%$ & $5 \%$ & $0 \%$ \\
\hline $\mathbf{7}$ & $\begin{array}{l}\text { Increased team motivation due to the use } \\
\text { of Scrum practices }\end{array}$ & $38 \%$ & $36 \%$ & $21 \%$ & $5 \%$ & $0 \%$ \\
\hline $\mathbf{8}$ & $\begin{array}{l}\text { Increased team productivity resulting from } \\
\text { the use of Scrum practices }\end{array}$ & $40 \%$ & $44 \%$ & $12 \%$ & $4 \%$ & $0 \%$ \\
\hline $\mathbf{9}$ & Increased control of project activities & $49 \%$ & $32 \%$ & $8 \%$ & $10 \%$ & $1 \%$ \\
\hline
\end{tabular}


ISSN: 2236-269X

DOI: 10.14807/ijmp.v8i5.598

\begin{tabular}{c|l|l|l|l|l|c}
\hline & $\begin{array}{l}\text { resulting from Daily Meetings resulting } \\
\text { from the use of Scrum practices }\end{array}$ & & & & \\
\hline $\mathbf{1 0}$ & $\begin{array}{l}\text { Improved follaboration among } \\
\text { stakeholders from the use of Scrum } \\
\text { practices }\end{array}$ & $44 \%$ & $39 \%$ & $14 \%$ & $3 \%$ & $0 \%$ \\
\hline $\mathbf{1 1}$ & $\begin{array}{l}\text { Visibility of activities by all team members } \\
\text { resulting from the use of Scrum practices }\end{array}$ & $60 \%$ & $27 \%$ & $11 \%$ & $2 \%$ & $0 \%$ \\
\hline $\mathbf{1 2}$ & $\begin{array}{l}\text { High agility for requirement adjustment at } \\
\text { design time [Scrum] }\end{array}$ & $34 \%$ & $41 \%$ & $14 \%$ & $8 \%$ & $3 \%$ \\
\hline $\mathbf{1 3}$ & $\begin{array}{l}\text { Scrum practices can contribute to project } \\
\text { closure faster }\end{array}$ & $34 \%$ & $42 \%$ & $17 \%$ & $4 \%$ & $3 \%$ \\
\hline $\mathbf{1 4}$ & $\begin{array}{l}\text { Scrum practices can contribute to lower } \\
\text { project costs }\end{array}$ & $23 \%$ & $41 \%$ & $24 \%$ & $6 \%$ & $6 \%$ \\
\hline
\end{tabular}

According to the data presented, it was verified that the majority of the respondents totally agreed with eight of the advantages and agreed partially with six advantages. This confirms the total convergence of the specialists in relation to the data from the literature review.

When analyzing the advantages of using project management practices in software development, it was found that the majority of the respondents, $80 \%$, agreed that the PMBOK offers a detail of planning and control, and about $88 \%$ agreed that both the PMBOK and Scrum practices promote improved communication among team members.

It is worth mentioning that $89 \%$ of the respondents considered the occurrence of learning in a short period provided through retrospectives of the Scrum iteration.

On the ease of use of Scrum a total of $83 \%$ agreement was obtained, while $66 \%$ of the respondents pointed the greater documentation provided by the PMBOK. In addition, $82 \%$ of respondents agreed on the advantage of having product running in short periods in Scrum.

It was also evidenced that $74 \%$ of the specialists answered that they agree with the increase of motivation of the team resulting from the use of Scrum practices.

In relation to the productivity increase of the Scrum practices a total of $84 \%$ was obtained, while $81 \%$ of the respondents agreed with the increased control of the project activities resulting from the daily meetings resulting from the Scrum practices;

The results also indicated that $83 \%$ of respondents agreed on improved collaboration between those involved in using Scrum practices. In addition, it was noted that: $87 \%$ of respondents agreed that Scrum practices provide visibility of activities by all team members; $75 \%$ of respondents agreed that Scrum provides high 
agility for requirement adjustment at design time; $76 \%$ of respondents agree that Scrum practices can contribute to project closure more quickly. In relation to the reduction of project costs resulting from the use of Scrum practices, a total of $64 \%$ of agreement was obtained.

It was observed that the degree of agreement in all items was expressive, that is, above $60 \%$, which indicates that these items have a positive evaluation of the experts regarding the proposed study.

\section{CONCLUSION}

Through the literature review, it was possible to identify 14 advantages related to the project management practices in several areas of application, which were submitted to the evaluation of specialists in the area of software development, to verify the degree of agreement of these experts on these criteria.

Based on these results, the present study is considered as an important contribution tool for the development of scientific knowledge about the advantages of the project management practices in software development.

Therefore, the main contribution that can be drawn from this work is a list of advantages identified based on the literature review on PMBOK and Scrum project management practices in software development. This study allowed the validation of these criteria identified by the specialists of the software development sector, corroborating the importance of this study.

Finally, the recommendation for future research is to carry out empirical studies of the case study that explore practical models of evaluation of the use of the practices studied in the scope of software development. It is important in the future study that metrics and indicators should be drawn for each advantage cited in the present study.

\section{REFERENCES}

ABRAHAMSSON, P. et al. (2002) Agile Software Development Method: Reviews and Analysis. Espoo: VTT Policátions. Disponível:

$<$ http://www.inf.vtt.fi/pdf/publications/2002/P478.pdf>. Acesso: 20/09/2015.

BARRETTO, C. et al. (2008) Estudo de utilização de Value Improving Pratices (VIP) enquanto práticas reconhecidas para melhoria de valor em projetos de capital, como fator chave para o sucesso destes empreendimentos. Curitiba: Fundação Getúlio Vargas. 
BECK, K. (1999) Embracing Change with Extreme Programming. IEEE Computer, v.32, n.10, p.70-77.

CARVALHO, B. V.; MELLO, C. H. P. (2012) Aplicação do método ágil scrum no desenvolvimento de produtos de software em uma pequena empresa de base tecnológica. Gestão da Produção, São Carlos, v. 19, n. 3, p. 557-573.

CERVONE, H. F. (2011) Understanding agile Project management methods using Scrum. OCLC System \& Services: International digital library perspectives, v.27, n. 1, p. 18-22.

COCKBURN, A. (2000) Selecting a Project's Methodology. IEEE Software, v.17, n.4, p. 64-71, July/Aug.

COSTA, H. G. (2010) Modelo de webibliomining: proposta e caso de aplicação.

Revista FAE, Curitiba, v.13, n.1, p. 115-126, jan./jun.

DANTAS, V. F. (2003) Uma metodologia para o desenvolvimento de aplicações Web num cenário global. Dissertação (Mestrado)-Centro de Ciências e Tecnologia, Universidade Federal de Campina Grande, Campina Grande.

DEY, P. K.; CLEGG, B. T.; BENNETT, D. J. (2010) Managing enterprise resource planning projects. Business Process Management Journal, Bradford, v. 16, n. 2, p. 282-296.

DINSMORE, P. C.; SILVEIRA NETO, F. H. (2005) Gerenciamento de Projetos: Como Gerenciar seu Projeto com Qualidade, dentro do Prazo e Custos Previstos. Rio de Janeiro: QualityMark.

EDER, S. et al. (2015) Diferenciando as abordagens tradicional e ágil de gerenciamento de projetos. Production Journal ,v.25, n. 3, p. 498-509.

EDER, S. et al. (2012) Estudo das práticas de gerenciamento de projetos voltadas para desenvolvimento de produtos inovadores. Produto \& Produção, Porto Alegre, v. 13, n. 1, p. 148-165, fev.

GHOSH, S. et al. (2012) Enhance PMBOK by Comparing it with P2M, ICB, PRINCE2, APM and Scrum Project Management Standards. PM World Today, v. 14, n. 1, p. 1-77.

HORTA, P. C. (2009) Gestão de mudanças versus fatores críticos de sucesso em implantação de sistema: um estudo de caso. Dissertação (Mestrado em Sistema de Gestão pela Qualidade Total) - Engenharia de Produção, Universidade Federal Fluminense, Niterói.

KAISER, M.G.; EL ARBI, F.; AHLEMANN, F. (2015) Successful project portfolio management beyond project selection techniques: Understanding the role of structural alignment. International Journal of Project Management. v. 33, n. 1, p. 126-139.

KING, G. R. (2014) Using the agile development methodology and applying best practice project management processes. Thesis. Monterey, California: Naval Postgraduate School.

LACERDA, R. T. D. O.; ENSSLIN, L.; ENSSLIN, S. R. (2011) A performance measurement view of IT project management. International Journal of Productivity and Performance Management, v.60, n. 2, p.132-151. 
LANDAETA, R. E.; VISCARDI, S.; TOLK, A. (2011) Strategic Management of Scrum Projects: An Organizational Learning Perspective. In: IEEE International Technology Management Conference (ITMC).

LARSON, R.; FARBER, B. (2007) Estatística aplicada. 2. ed. São Paulo: PrenticeHall.

LIKERT, R. A. (1932) Technique for measurement of attitudes. Archives of Psychology, v. 140, n. 1, p. 5-55.

MACHADO, T. C. S.; PINHEIRO, P. R.; TAMANINI, I. (2015) Project management aided by verbal decision analysis approaches: a case study for the selection of the best SCRUM practices. International Transactions in Operational Research, v. 22, n. 2, p. 287-312.

MARTINS, J. C. C. (2002) Gestão de Projetos de Desenvolvimento de Software. Rio de Janeiro: Brasport.

NASCIMENTO, T. C. et al. (2014) Fatores que contribuem para a maturidade em gerenciamento de projetos: o caso de um governo estadual. Revista de

Administração, São Paulo, v. 49, n. 2, p. 415-428, abr./jun.

PFLEEGER, S. L. (2004) Engenharia de Software: Teoria e Prática. São Paulo: Prentice Hall.

PRESSMAN, Roger S. (2006) Engenharia de Software. 6. ed. São Paulo: McGraw Hill.

PROJECT MANAGEMENT INSTITUTE (2013) A guide to the Project

Management of Body of Knowledge (PMBOK). 5. ed. Pennsylvania, PA, USA:

Project Management Institute.

SCHWALBE, K. (2002) Information Technology Project Management.

Cambridge, MA: Course Technology.

SCHWABER, K.; BEEDLE, M. (2002) Agile Software Development with Scrum.

Prentice-Hall.

SENGE. P. (1990) The fifth discipline: the art and practice of the learning organization. New York: Currency.

SHENHAR, J. A.; DVIR, D. (2007) Reinventing project: the diamond approach to successful growth and innovation. Boston, Massachusetts: Harvard Business School Publishing.

SOMMERVILLE, I. (2004) Software Engineering. Addison-Wesley Longman Publishing Co.

TAKEUCHI, H.; NONAKA, I. (2004) Hitotsubashi on knowledge management. Singapore: John Wiley \& Sons.

THOMSETT, R. (2001) Extreme Project Management, Business-IT Strategies Advisory Service. Executive Report, v.2, n.2. 